\title{
Total Synthesis of Clausenain, a Cyclic Octapeptide and its Analog for Anticancer Activity
}

\author{
Nirmala Shinde ${ }^{1, \star}$ Avinash Shridhar Dhake ${ }^{1}$, Kishan Prabhu Haval ${ }^{2}$, Sachin Kawaduji Bhosale ${ }^{1}$ \\ ${ }^{1}$ Department of Pharmaceutical Chemistry, S.M.B.T. College of Pharmacy, Nandi Hills, Dhamangaon. Igatpuri, Nashik, \\ Maharashtra, INDIA. \\ ${ }^{2}$ Department of Chemistry, Dr. Babasaheb Ambedkar Marathwada University, (Subcentre) Osmanabad, Maharashtra, INDIA.
}

\begin{abstract}
Keeping in mind requisite of today's era for development of new anticancer drugs, synthesis of a phenyl alanine rich cyclic octapeptide Clausenain and its analog by solution phase technique is described here. It was done through coupling a tetrapeptide BOC-Phe-Ser-Leu-Phe-OMe with another tetrapeptide BOC-Phe-Gly-Leu-Phe-OMe after proper deprotection towards carboxyl and amino terminals. The $\mathrm{N}$-methyl analog of this octapeptide was prepared with $\mathrm{N}$-methylated Glycine instead of Glycine as starting material. The linear peptides were then cyclized using suitable procedure. The establishment of structure for synthesized compounds was done by spectral and elemental analysis. Evaluation of synthesized compounds was done by brine shrimp lethality assay and further screening was done using a panel of 60 human tumor cell lines. The cyclic octapeptide and its analog showed good activity against cells lines of Leukemia, Non-small cell lung cancer, CNS cancer, breast cancer and renal cancer in comparison with vincristine as standard. The $\mathrm{N}$-methylated analog was found to be more active than the cyclic peptide.
\end{abstract}

Key words: Octapeptide, Solution phase technique, p-nitro phenyl ester method, Brine shrimp, Anticancer, Tumor cell lines.

\section{INTRODUCTION}

Development of novelanticancer drugs from natural cradles has always been fascinating for medicinal chemist and researchers who are actively involved in the process of drug discovery. Cyclic peptides are found to be of more medicinal importance as they show a number of biological activities resembling anti-inflammatory, antimicrobial, serine protease, cytotoxic, anti-HIV and protein tyrosine phosphatase inhibitory activity. ${ }^{1-7}$ Besides all the activities shown by natural bioactive peptide, they can be obtained with low yield from natural sources. In an attempt to obtain such bioactive peptide with good yield, the total synthesis of Clausenain, a phenyl alanine rich cyclic octapeptide, cyclo(Phe-Ser- Leu- Phe -Phe-Gly-Leu-Phe), isolated from Clausena anisum-olens, a shrub from south of China, belonging to family
Rutaceae was carried out. ${ }^{8} \mathrm{~N}$-methylated analog of this cyclic octapeptide was also synthesized using solution phase technique. Cyclization of the linear fragments was achieved by p-nitro phenyl ester method. ${ }^{10}$ Confirmation of structure for the synthesized compounds was done by spectral and elemental analysis. The compounds were then preliminary assayed for cytotoxicity by Brine shrimp method and then subjected to screening against a panel of 60 different human tumor cell lines at National Cancer Institute, USA. The results of screening for anticancer activity revealed that the compound is active against cells lines of Leukemia, CNS cancer, Nonsmall cell lung cancer, renal cancer and breast cancer when assessed with vincristine
Submission Date: 12-08-2019; Revision Date: 21-01-2020; Accepted Date: 26-02-2020

DOI: 10.5530/ijper.54.2s.90 Correspondence: Dr. Nirmala Shinde Department of Pharmaceutical Chemistry, S.M.B.T. College of Pharmacy, Nandi Hills, Dhamangaon. Tah: Igatpuri, Dist: Nashik-422403 Maharashtra, INDIA.

Phone: +91-9765239132

E-mail: nirmalampharm@ rediffmail.com

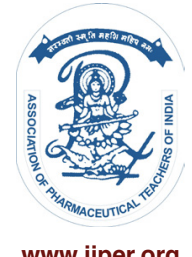

www.ijper.org 
as standard. Its $\mathrm{N}$-methylated analog was found to be more active than the cyclic peptide.

\section{MATERIALS AND METHODS}

All reactions necessitating anhydrous environments were carried out using flame dried apparatus. The chemicals utilised in this synthesis are L-amino acids, di-tert butyldicarbonate $\left(\mathrm{Boc}_{2} \mathrm{O}\right)$, trifluoroacetic acid (TFA), diisopropylcarbodiimide (DIPC), triethylamine (TEA), pyridine $\mathrm{N}$-methylmorpholine (NMM), pyridine and p-nitro phenol were procured from Spectrochem Ltd., Mumbai. Digital melting point apparatus was used to determine the melting point. Completion of reaction and purity of intermediates, synthesized compounds was checked using precoated TLC plates utilizing suitable developing solvent. FTIR spectrophotometer, JASCO 4100 was used to record the IR spectra using $\mathrm{KBr}$ pellets for solids and using chloroform and $\mathrm{NaCl}$ cells for semisolids.

Bruker AC NMR spectrometer was used to record ${ }^{1} \mathrm{H}$ NMR and ${ }^{13} \mathrm{C}$ NMR spectra with TMS as an internal standard and $\mathrm{CDCl}_{3}$ as a solvent. JMS-DX 303 Mass spectrometer operating at $70 \mathrm{eV}$ was used to record the MASS spectrum by ESIMS/MS.

Synthesis of Clausenain and its analog (Scheme 1): Solution phase technique was used to synthesize the titled compounds. ' The total synthesis of cyclic peptide, Clausenain, cyclo-(Phe-Ser-Leu-Phe -Phe-GlyLeu-Phe), was achieved by disconnecting it into four dipeptide units, BOC-Phe-Ser-OMe (1), BOC-Leu-Phe -OMe (2), BOC-Phe-Gly-OMe (3) and Boc-Leu-Phe$\mathrm{OMe}(4)$.

Coupling of the Boc-amino acids with particular amino acid methyl esters was done by means of DIPC as a coupling agent to obtain the dipeptides. Deprotection of the ester group of dipeptide 1 and 3 and Boc- group of dipeptide 2 and 4 was done using $\mathrm{LiOH}$ and TFA respectively. The deprotected components were then coupled to grow two tetra peptides BOC- Phe-Ser- LeuPhe (5) and BOC-Phe-Gly-Leu-Phe-OMe (6). In order to prepare the $\mathrm{N}$-methylated analog, methylation was done for amino acid Glycine so as to obtain tetrapeptide as BOC- Phe-(N-Me)Gly -OMe $\left(6^{*}\right)$. The subsequent tetrapeptides were coupled using DIPC and chloroform to get a linear octapeptide $(7,7 \mathrm{a})$, which were then cyclized using p-nitro phenyl ester method to develop titled compound $(8,8 \mathrm{a})$.

General method for preparation of Di/Tetra/linear octapeptide: ${ }^{11-13} 10 \mathrm{mmol}$ of L-Amino acid methyl ester $\mathrm{HCl}$ / dipeptide methyl ester/tetra peptide methyl ester was added to $20 \mathrm{ml} \mathrm{CHCl}_{3}$, followed by adding TEA
$(2.8 \mathrm{ml}, 20 \mathrm{mmol})$ at $0^{\circ} \mathrm{C}$ and stirring for $15 \mathrm{~min}$. To the above reaction mixture, $10 \mathrm{mmol}$ of Boc-L-amino acid/ Boc-dipeptide/Boc-tetrapeptide, $20 \mathrm{ml}$ chloroform and $10 \mathrm{mmol}$ DIPC were added with stirring and the reaction was carried out for $24 \mathrm{hr}$. The reaction mixture was then filtered and using $30 \mathrm{ml}$ chloroform the residue was washed and mixed to the filtrate. The filtrate was again washed using $5 \% \mathrm{NaHCO}_{3}$ and saturated $\mathrm{NaCl}$ solutions. Anhydrous $\mathrm{Na}_{2} \mathrm{SO}_{4}$ was used to dry the organic layer followed by filtration and evaporation in vacuum. The crude product was recrystallized using a mixture of petroleum ether and chloroform, followed by cooling at $0^{\circ} \mathrm{C}$. By using this procedure, compounds 1-7, 7a were synthesized.

\section{Cyclization of linear octapeptide: ${ }^{10}$}

The ester group of linear fragment (7, 7a) was deprotected with $\mathrm{LiOH}$ and the $p$-nitro phenyl ester group was introduced by dissolving $1.5 \mathrm{mmol}$ Bocpeptide carboxylic acid in $15 \mathrm{ml}$ chloroform at $0^{\circ} \mathrm{C}$ followed by addition of $2 \mathrm{mmol}$ p-nitro phenol. It was stirred at RT for $12 \mathrm{~h}$. The reaction mixture was filtered and filtrate was washed with $10 \% \mathrm{NaHCO}_{3}$ solution to remove excess of p-nitro phenol. It was finally washed with $5 \mathrm{ml}$ of $5 \% \mathrm{HCl}$ to obtain Boc-peptide-pnp ester. $1.2 \mathrm{mmol}$ of above Boc-peptide-pnp-ester, $15 \mathrm{ml}$ of $\mathrm{CHCl}_{3}$ and $2.4 \mathrm{mmol} \mathrm{CF}_{3} \mathrm{COOH}$ were stirred for $1 \mathrm{hr}$ at RT and washed with $10 \% \mathrm{NaHCO}_{3}$. The organic layer was dried with anhydrous $\mathrm{Na}_{2} \mathrm{SO}_{4}$ to obtain Bocdeprotected peptide-pnp-ester, to which $15 \mathrm{ml} \mathrm{CHCl}_{3}$, $\mathrm{N}$-methyl morpholine $(1.4 \mathrm{ml}, 2 \mathrm{mmol}$.) was added and set aside at $0^{\circ} \mathrm{C}$ for $7 \mathrm{~d}$. The reaction mixture was washed using $10 \% \mathrm{NaHCO}_{3}$ to remove excess of $p$-nitrophenol followed by washing with $5 \% \mathrm{HCl}(5 \mathrm{ml})$. The organic layer was then dried with anhydrous $\mathrm{Na}_{2} \mathrm{SO}_{4}$. Chloroform and pyridine were distilled off to get crude product which was recrystallized from $\mathrm{CHCl}_{3} / \mathrm{n}$-hexane to get the titled compound $(8,8 \mathrm{a})$.

\section{Anticancer activity of synthesized compound}

Brine Shrimp Lethality assay for preliminary cytotoxicity: ${ }^{14,15}$ Procurement of Brine shrimp eggs was done from the aquarium shop, Nasik. Preparation of artificial sea water was done using distilled water ( $35 \mathrm{~g} / \mathrm{l})$ and $1 \% \mathrm{NaCl}$ at $25^{\circ} \mathrm{C}$ under constant illumination. The solution was continuously aerated using an aquarium air pump. A hatching chamber having divider for dark and light areas was utilized to introduce the seawater. The shrimp eggs were placed to the dim side of chamber whereas the lamp present on other side will entice hatched shrimp. After two days, the shrimps hatched and matured as nauplii. The test compounds were prepared 
by using DMSO and sea water. In each test tube, $4 \mathrm{ml}$ of the artificial seawater was transferred followed by addition of different conc. of drug in triplicate. To each of the test tubes, 10 brine shrimps were introduced so as to get 30 shrimps per dilution and final volume was made up to $5 \mathrm{ml}$ using artificial seawater. The test tubes were left exposed to the lamp for $24 \mathrm{hr}$. The number of alive shrimps were recorded after $24 \mathrm{hr}$ and lethality concentration $\left(\mathrm{LC}_{50}\right)$ was measured at confidence interval of $95 \%$. The percentage mortality $(\% \mathrm{M})$ was also determined to assess the activity of the compound. The outcomes of activity are shown in Table 1.

\section{In vitro cytotoxic activity against Human tumor cell lines ${ }^{2,16-21}$}

The in vitro anticancer screening of the synthesized compounds was done at National Cancer Institute, Bathesda, USA in a panel of 60 human tumor cell lines of the leukemia, Non-small cell lung, colon, CNS, melanoma, ovarian, renal, prostate and breast cancers etc. Its objective is to show selective growth inhibition of specific tumor cell lines by test compound. The screening for selected compounds was initially carried out at single dose of $10^{-5} \mathrm{M}$. The results of screening are reported as a mean graph. The Graph 1, 2 and Table 2 shows result of anticancer screening for synthesized compounds. The results obtained were compared with mean graph of Vincrstine as standard. The comparative data for $\%$ GI against different human tumor cell lines by Clausenain and its analog is shown in the Table 2.

\section{RESULTS AND DISCUSSION}

\section{Characterization for compound 8}

Physical state: Semisolid mass, IR Data: intense N-H and $\mathrm{C}=\mathrm{O}$ absorptions at 3433 and $1640,1660 \mathrm{~cm}^{-1}$ respectively, FABMS: $\mathrm{M}^{+}$ion peak at $m / z .959,{ }^{13} \mathrm{C}$ NMR: 156.37-177.36 (-CONH, cyclic ring), 115.84-136.34 (Ar, 4 Phe), 55.11-58.81 (CH, cyclic ring), $60.20\left(\mathrm{CH}_{2}\right.$, Ser), $42.22\left(\mathrm{CH}_{2}, \mathrm{Gly}\right), 41.96\left(\mathrm{CH}_{2}, \mathrm{Leu}\right), 37.66\left(4 \mathrm{CH}_{2}, 4\right.$ Phe), 21.55-21.79 (2CH, Leu), 19.57-21.55 (4- $\mathrm{CH}_{3}, 2$ Leu), ${ }^{1} \mathrm{H}$ NMR: 8.11-8.16 ( $8 \mathrm{~N}-\mathrm{H}$ of amide linkage), 7.15-7.26(20H, 4 Ar, 4Phe), 4.1969 $\left(2 \mathrm{H}, \mathrm{CH}_{2}\right.$ Cyclic peptide), 4.1969-4.1994 (7H, CH of cyclic peptide), $3.93\left(2 \mathrm{H}, \mathrm{CH}_{2}\right.$, Gly), 2.52(1H, OH, Ser), 1.05-1.17(12H, $\left.4 \mathrm{CH}_{3}, 2 \mathrm{Leu}\right), 1.30-1.33\left(4 \mathrm{H}, 2 \mathrm{CH}_{2}, 2 \mathrm{Leu}\right), 1.40-1.41(2 \mathrm{H}$, 2CH, 2 Leu), Elemental analysis: $\mathrm{C}=66.46(66.37) \%$, $\mathrm{H}=7.13(6.94) \%, \mathrm{~N}=11.63(11.66) \%$.

\section{Characterization for compound $8 \mathrm{a}$}

Physical state: Semisolid mass, IR Data: intense $\mathrm{N}-\mathrm{H}$ and $\mathrm{C}=\mathrm{O}$ absorptions at 3300 and 1650 $\mathrm{cm}^{-1}$ respectively, amino and amide carbonyl groups at $3427,1650 \mathrm{~cm}^{-1}$ respectively, $1693.7\left(\mathrm{~N}^{-\mathrm{CH}_{3}}\right.$ stretch) due to $\mathrm{N}_{-} \mathrm{CH}_{3}$ stretch, FABMS: $\mathrm{M}^{+}$ion peak at $\mathrm{m} / \mathrm{z} 973$

${ }^{13} \mathrm{C}$ NMR: 157.01-173.68 (-CONH cyclic ring), 115.84136.34 (Ar, 4 Phe), 55.11-58.81 (CH, cyclic ring), $60.20\left(\mathrm{CH}_{2}, \mathrm{Ser}\right), 42.22\left(\mathrm{CH}_{2}, \mathrm{Gly}\right), 41.96\left(\mathrm{CH}_{2}, \mathrm{Leu}\right)$, $37.66\left(4 \mathrm{CH}_{2}, 4\right.$ Phe), 21.55-21.79 (2CH, Leu), 19.57$21.55\left(4-\mathrm{CH}_{3}, 2 \mathrm{Leu}\right), 157.01-173.68$ (-CONH cyclic ring), $30.29\left(\mathrm{~N}^{-} \mathrm{CH}_{3}\right),{ }^{1} \mathrm{H}$ NMR: 8.1177-8.1603 ( 7 $\mathrm{N}-\mathrm{H}$ of amide linkage), 7.15-7.26 (20H, $4 \mathrm{Ar}$, 4Phe), $4.19\left(2 \mathrm{H}, \mathrm{CH}_{2}\right.$ Cyclic peptide), 4.1969-4.1994 (7H, $\mathrm{CH}$ of cyclic peptide), $3.93\left(2 \mathrm{H}, \mathrm{CH}_{2}, \mathrm{Gly}\right), 2.97(3 \mathrm{H}$, $\left.\mathrm{N}-\mathrm{CH}_{3}\right), 2.982-3.61\left(8 \mathrm{H}, 4 \mathrm{CH}_{2}, 4 \mathrm{Phe}\right), 2.52(1 \mathrm{H}, \mathrm{OH}$, Ser), $1.05-1.17\left(12 \mathrm{H}, 4 \mathrm{CH}_{3}, 2 \mathrm{Leu}\right), 1.30-1.33\left(4 \mathrm{H}, 2 \mathrm{CH}_{2}\right.$, 2Leu), 1.40-1.41(2H, 2CH, $2 \mathrm{Leu})$, Elemental analysis: $\mathrm{C}=66.51(66.65) \%, \mathrm{H}=7.45(7.04) \%, \mathrm{~N}=11.62(11.51) \%$.

Results of Anticancer screening: The results of cytotoxic activity by using Brine shrimp assay indicates greater activity for methylated clausenain $\left(\mathrm{LC}_{50}=41.42\right)$ compared to clausenain.

Anticancer screening against human tumor cell lines: Vincristine, an established drug in the treatment of various types of cancers like Leukemia, lymphomas, sarcomas, liver cancer, head and neck cancer, was used as a reference compound for comparison. Clausenain showed potent activity against various cell lines of leukemia (CCRF-CEM, MOLT-4, RPMI-8286 and SR cell lines), Non-small cell lung cancer (A549-ATCC cell lines), CNS cancer (SF-295 and U251 cell lines), renal cancer (786-0, CAKI-1, SN 12C, TK-10, UO-31 and breast cancer (MCF-7). The \% growth inhibition shown by $\mathrm{N}$-methylated analog is more than Clausenain against various cell lines of Leukemia (CCRF-CEM, K 562, MOLT-4 and RPMI-8286), Non-small cell lung cancer (A549-ATCC cell lines), Colon cancer (HCT116),

\begin{tabular}{|c|c|c|c|c|c|c|c|}
\hline \multirow{2}{*}{$\begin{array}{c}\text { Comp. } \\
\text { Conc. }(\mu \mathrm{g} / \mathrm{ml})\end{array}$} & \multicolumn{6}{|c|}{$\%$ Mortality at various concentration } & \multirow[t]{2}{*}{$\mathrm{LC}_{50}$} \\
\hline & 25 & 50 & 100 & 150 & 200 & 250 & \\
\hline 8 & 36.66 & 46.66 & 56.66 & 66.66 & 80 & 90 & 73.95652 \\
\hline $8 a$ & 43.33 & 55.66 & 63.33 & 73.33 & 86.66 & 96.66 & 41.42222 \\
\hline
\end{tabular}

$\mathrm{LC}_{50}$ is the concentration required to kill the $50 \%$ of brine shrimps by the test compounds. 


\begin{tabular}{|c|c|c|c|c|c|c|c|}
\hline \multirow{2}{*}{$\begin{array}{c}\text { Human } \\
\text { Tumor Cell } \\
\text { Line }\end{array}$} & \multicolumn{3}{|c|}{$\%$ Growth Inhibition } & \multirow{2}{*}{$\begin{array}{c}\text { Human Tumor } \\
\text { Cell Line }\end{array}$} & \multicolumn{3}{|c|}{$\%$ Growth Inhibition } \\
\hline & 8 & $8 a$ & Vincristine & & 8 & $8 a$ & Vincristine \\
\hline $\begin{array}{c}\text { Leukemia } \\
\text { CCRF-CEM } \\
\text { K } 562 \\
\text { MOLT-4 } \\
\text { RPMI-8226 } \\
\text { SR }\end{array}$ & $\begin{array}{l}4.40 \\
0.68 \\
6.71 \\
6.23 \\
8.74\end{array}$ & $\begin{array}{c}5.29 \\
7.24 \\
30.85 \\
18.94 \\
0.53\end{array}$ & $\begin{array}{c}4.498 \\
10.89 \\
5.298 \\
16.2 \\
0.5\end{array}$ & $\begin{array}{l}\text { Ovarian } \\
\text { Cancer } \\
\text { IGROV1 } \\
\text { OVCAR-3 } \\
\text { OVCAR-4 } \\
\text { OVCAR-5 } \\
\text { SK-OV-3 }\end{array}$ & $\begin{array}{c}3.20 \\
- \\
- \\
2.34 \\
4.77\end{array}$ & $\begin{array}{c}- \\
8.35 \\
14.40 \\
- \\
-\end{array}$ & $\begin{array}{c}6.3 \\
51.7 \\
-38.9 \\
57.9 \\
18.2\end{array}$ \\
\hline $\begin{array}{l}\text { Non-Small } \\
\text { cell Lung } \\
\text { Cancer } \\
\text { A549/ATCC } \\
\text { NCl-H226 } \\
\text { NCl-H522 }\end{array}$ & $\begin{array}{c}0.35 \\
4.19 \\
20.08\end{array}$ & $\begin{array}{c}0.84 \\
- \\
18.42\end{array}$ & $\begin{array}{c}-6.3 \\
-17.9 \\
23.40\end{array}$ & $\begin{array}{c}\text { Renal Cancer } \\
786-0 \\
\text { ACHN } \\
\text { CAKI-1 } \\
\text { RXF393 } \\
\text { SN12C }\end{array}$ & $\begin{array}{c}4.72 \\
- \\
14.22 \\
1.58 \\
2.67\end{array}$ & $\begin{array}{c}- \\
8.45 \\
21.54 \\
- \\
-\end{array}$ & $\begin{array}{c}-2.1 \\
-26.00 \\
-16.2 \\
46.3 \\
-29.6\end{array}$ \\
\hline $\begin{array}{c}\text { Colon cancer } \\
\text { HCT-116 }\end{array}$ & 7.12 & 21.11 & 47 & $\begin{array}{r}\text { TK-10 } \\
\text { UO-31 }\end{array}$ & $\begin{array}{c}23.68 \\
-\end{array}$ & 14.12 & $\begin{array}{l}-50.5 \\
-18.3\end{array}$ \\
\hline $\begin{array}{l}\text { HCT-15 } \\
\text { SW-620 }\end{array}$ & $\begin{array}{l}4.68 \\
1.85\end{array}$ & - & $\begin{array}{l}-0.6 \\
-5.2\end{array}$ & $\begin{array}{c}\text { Prostate } \\
\text { Cancer } \\
\text { PC-3 }\end{array}$ & - & 35.81 & -8.00 \\
\hline $\begin{array}{c}\text { CNS Cancer } \\
\text { SF-295 } \\
\text { SNB-19 } \\
\text { SNB-75 } \\
\text { U251 }\end{array}$ & $\begin{array}{c}7.79 \\
- \\
- \\
0.94\end{array}$ & $\begin{array}{c}- \\
32.40 \\
9.73 \\
-\end{array}$ & $\begin{array}{c}-3.3 \\
0.2 \\
-5.4 \\
-13.9\end{array}$ & $\begin{array}{c}\text { Breast Cancer } \\
\text { MCF7 } \\
\text { BT-549 } \\
\text { T-47D }\end{array}$ & $\begin{array}{c}8.64 \\
12.10 \\
-\end{array}$ & $\begin{array}{c}15.23 \\
- \\
10.99\end{array}$ & $\begin{array}{c}7.9 \\
34.5 \\
-48.5\end{array}$ \\
\hline $\begin{array}{c}\text { Melanoma } \\
\text { MALME-3 } \\
\text { M14 } \\
\text { SK-MEL-5 } \\
\text { UACC-257 } \\
\text { UACC-62 }\end{array}$ & $\begin{array}{l}2.11 \\
5.10 \\
1.22 \\
1.26 \\
-\end{array}$ & $\begin{array}{c}- \\
- \\
- \\
6.58 \\
0.10\end{array}$ & $\begin{array}{l}0.68 \\
4.45 \\
2.29 \\
2.36 \\
4.84\end{array}$ & $\begin{array}{c}\text { Mean } \\
\text { Delta } \\
\text { Range }\end{array}$ & $\begin{array}{c}100.47 \\
23.68 \\
47.69\end{array}$ & $\begin{array}{l}81.94 \\
35.81 \\
60.40\end{array}$ & $\begin{array}{c}10.298 \\
83.79 \\
363.9\end{array}$ \\
\hline
\end{tabular}

$\% \mathrm{Gl}$ is percent of particular cell line growth inhibited by the test compounds

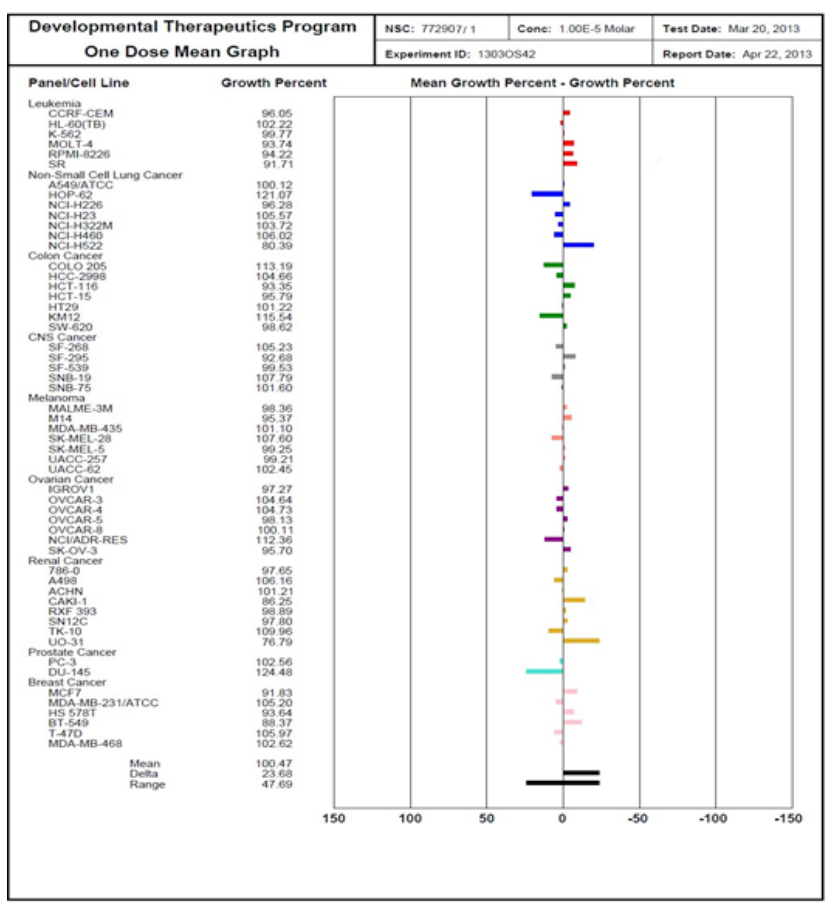

Graph 1: DTP One dose Mean graph for Clausenain (8).

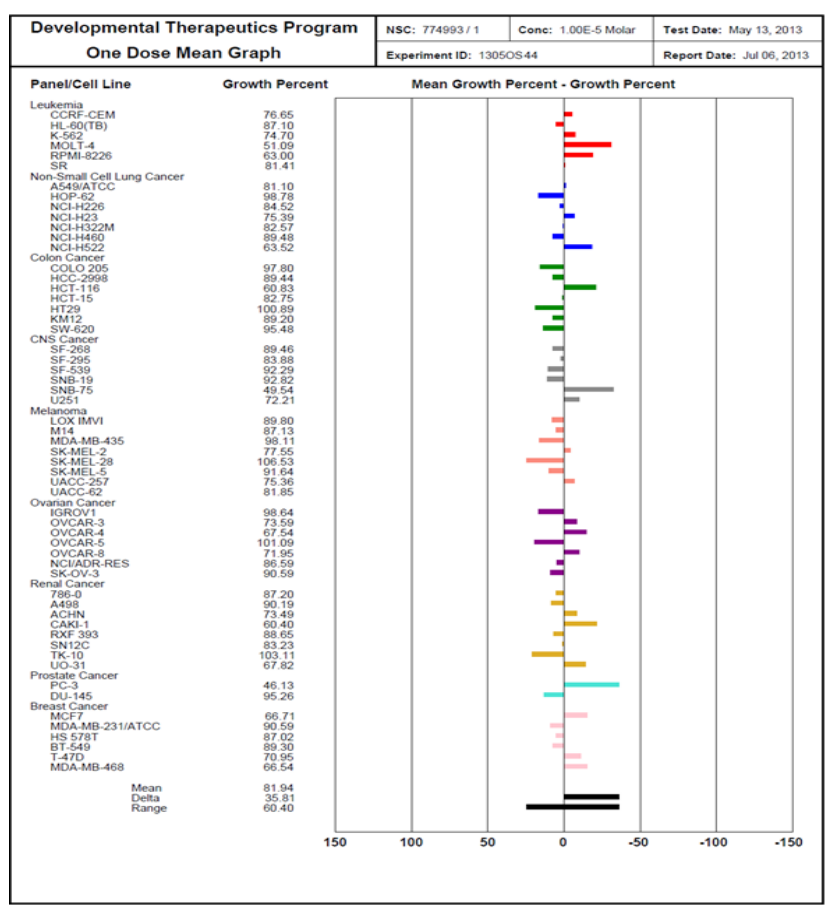

Graph 2: DTP One dose Mean graph for N-methylated analog of Clausenain (8a). 


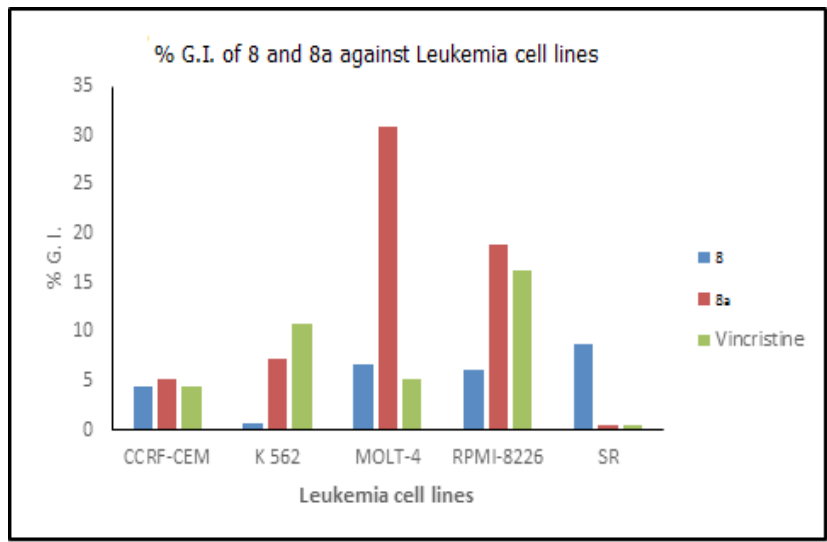

Graph 3: Comparison of anticancer screening of 8 and $8 a$ against leukemia cell lines.

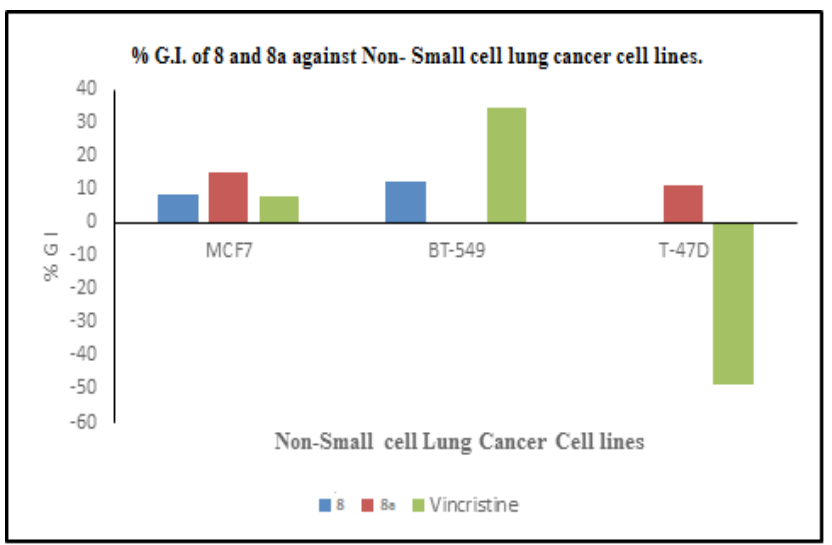

Graph 4: Comparison of anticancer screening of 8 and $8 a$ against Non-small cell Lung cancer cell lines.

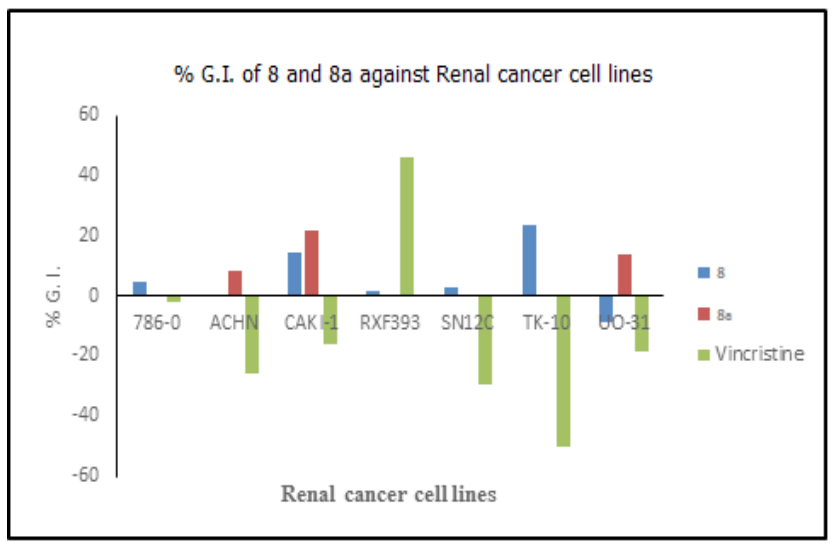

Graph 5: Comparison of anticancer screening of 8 and $8 a$ against Renal cancer cell lines.

Melanoma (UACC-257), renal cancer (CAKI-1), breast cancer (MCF-7, T-47D). The results are represented by using Graph 3-6.

\section{CONCLUSION}

The designed compounds were synthesized with good yield using solution phase technique. The $\mathrm{N}$-methylated analog was found to be more active than Clausenain.

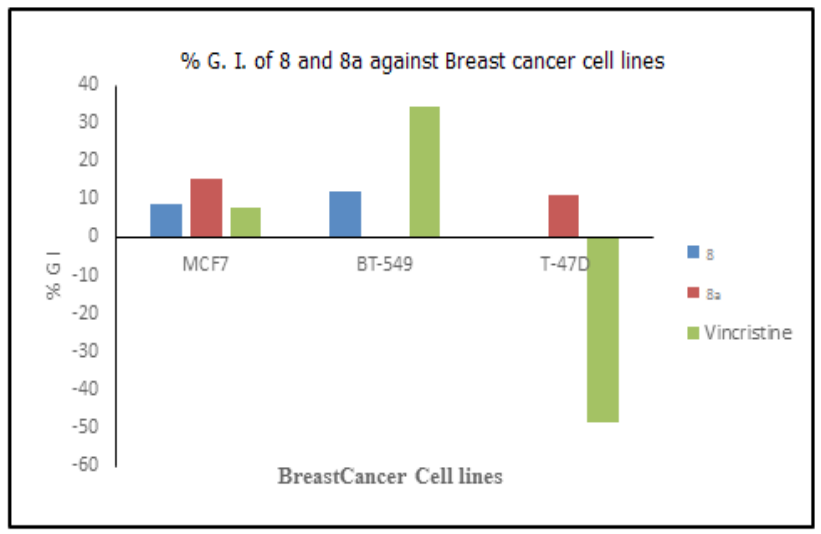

Graph 6: Comparison of anticancer screening of 8 and $8 a$ against Breast cancer cell lines.

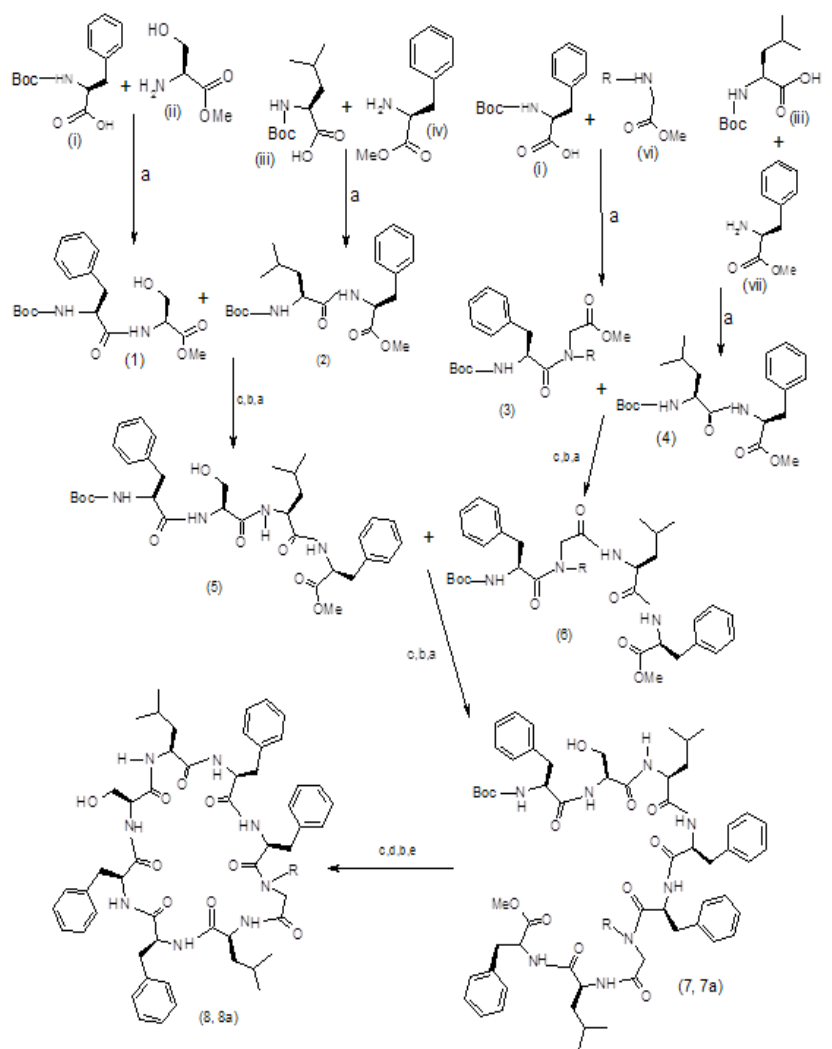

Where: a= DIPC, NMM, $\mathrm{CHCl}_{3}$, RT, 24h, b= TFA, NMM, RT, 1h, c= $\mathrm{LiOH}, \mathrm{THF}: \mathrm{H}_{2} \mathrm{O}(1: 1)$, reflux, 15 mins d= pnp-, $\mathrm{CHCl}_{3}, \mathrm{RT}, 12 \mathrm{~h}, \mathrm{e}=$ $\mathrm{NMM}, \mathrm{CHCl}_{3}, 0^{\circ} \mathrm{C}, 7$ days

Scheme 1: Synthetic route for Clausenain and its analog (8, 8a).

The presence of $\mathrm{N}$-methyl group changes the hydrogen bonding pattern, making the molecule more constrained thus increasing affinity, selectivity and membrane permeability of the molecule. The presence of $\mathrm{N}$-methyl group modifies its profile of anticancer activity against many cell lines. Further modification in the structure of this molecule possibly will result a novel anticancer analog. 


\section{ACKNOWLEDGEMENT}

Authors are thankful to S.M.B.T. College of Pharmacy, Dhamangaon, Nashik for providing necessary facilities to do the research work and SAIF, Chandigarh for spectral analysis, NCI, Bethesda, USA for carrying out anticancer activity.

\section{CONFLICT OF INTEREST}

The authors declare no conflict of interest.

\section{ABBREVIATIONS}

DIPC: Diisopropyl carbodiamide; BOC: t-butyloxycarbodiimide; TFA: Trifluoroacetic acid; TEA: Triethylamine; NMM: N-methylmorpholine.

\section{REFERENCES}

1. Shinde NV, Himaja M, Bhosale SK, Ramana MV, Sakarkar DM. Synthesis and Biological Evaluation of Delavayin-C. Indian J Pharm Sci. 2008;70(6):695852.

2. Shinde NV, Dhake AS, Haval KP. Design, synthesis and in vitro cytotoxic activity of Delavayin A: A cyclic hexapeptide. African Journal of Pharmacy and Pharmacology. 2016;10(10):170-8.

3. Dahiya R, Pathak D. First total synthesis and biological evaluation of halolitoralin. American Journal of Serbian Chemical Society. 2007;72(2):1017.

4. Kumar S, Dahiya R, Khokra SL, Gupta SV, Sutariya VB, Bhatia D. Toward the Synthesis and Improved Biopotential of an N-methylated Analog of a ProlineRich. Cyclic Tetrapeptide from Marine Bacteria. 2018;16(9):305.

5. Kumar S, Dahiya R, Khokra SL, Mourya R, Suresh V, et al. Total Synthesis and Pharmacological Investigation of Cordyheptapeptide A. Molecules. 2017;22(6):682.

6. Dahiya R, Gautam H. Total synthesis and antimicrobial activity of a natural cycloheptapeptide of marine origin. Marine Drugs. 2010;8(8):2384-94.

7. Dahiya R, Gautam H. Towards the Synthesis and Biological Screening of a Cyclotetrapeptide. Marine Drugs. 2011;9(1):71-81.
8. Shinde NV, Dhake AS, Haval KP. First total synthesis and biological screening of cyclic tetrapeptides from Onychocola sclerotica. Der Pharma Chemica. 2015;7(11):251-7.

9. Chatterjee J, Laufer B, Kessler $\mathrm{H}$. Synthesis of $\mathrm{N}$-methylated cyclic peptides Nature Protocols. 2012;7(3):432-44

10. Bodanszky $M$, Bodanszky A. Cyclization of linear peptide by using p-nitrophenyl ester method. Practice of peptide synthesis springer-verlog. New York. 1984;78:143.

11. Shinde NV, Dhake AS, Haval KP. Synthesis, characterization and anticancer screening of psammosilenin B: A cyclic octapeptide. Asian Journal of Chemistry. 2015;27(3):1153-6.

12. Shinde NV, Dhake AS, Haval KP. Towards the First Total Synthesis and Anticancer Screening of Polycarponin C: A Cyclic Octapeptide. Oriental Journal of Chemistry. 2016;32(1):515-21.

13. Poojary B, Belagali SL. Synthesis, Characterization and biological evaluation of cyclic peptides. Viscumamide, Yunnanin A and Evolidine. Z. Naturforsch. 2005;60b(12):1313-20.

14. Meyer BN, Putnam JE, Nichols DE, McLaughlin JL. Brine shrimp: A convenient general bioassay for active plant constituents. Journal of Medicinal Plant Research. 1982;45(5):31-4.

15. Bhosale SK, Deshpande SR, Wagh RD. 3-(4-chlorophenyl)-[1, 2, 3] oxadiazol3-ium-5-olate and its 4-formyl analog-Ultrasound assisted synthesis and invitro anticancer evaluation against human tumor cell lines. Pakistan Journal of Pharmaceutical Sciences. 2017;30(02):513-20.

16. www.nci.gov.in

17. Lorenzi PL, Reinhold WC, Varma S, Hutchinson AA, Pommier Y, Chanock $\mathrm{SJ}$, et al. DNA Fingerprinting of the $\mathrm{NCl} 60$ cell line panel. Molecular Cancer Therapeutics. 2009;8(4):713-24.

18. Mingyi M, Longru $\mathrm{S}$, Ji M. Synthesis and biological evaluation of Combretastatin A-4 derivatives containing a 3'-O-substituted carbonic ether moiety as potential antitumor agents. Chemistry Central Journal. 2013;7(1):179.

19. Bhosale SK, Deshpande SR, Shinde NV. Design, ultrasound assisted synthesis and anticancer screening of 4-[5-(aryl)-4,5-dihydro-1 phenyl-pyrazol3-yl]-3-(substitutedphenyl)sydnones. J Indian Chem Soc. 2019;(96):1075-84.

20. Al-Suwaidan IA, Alanazi AM, Abdel-Aziz AA, Mohamed MA, El-Azab AS. Design, synthesis and biological evaluation of 2-mercapto-3phenethylquinazoline bearing anilide fragments as potential antitumor agents: Molecular docking study. Bioorganic Medicinal Chemistry Letters. 2013;23(13):3935-41.

21. Ghosh KCH, Duttagupta I, Bose C, Banerjee P, Gayen AK, Sinha S. Synthesis and anticancer activities of proline-containing cyclic peptides and their linear analogs and congeners. An International Journal for Rapid Communication of Synthetic Organic Chemistry. 2019;49(2):221-36.

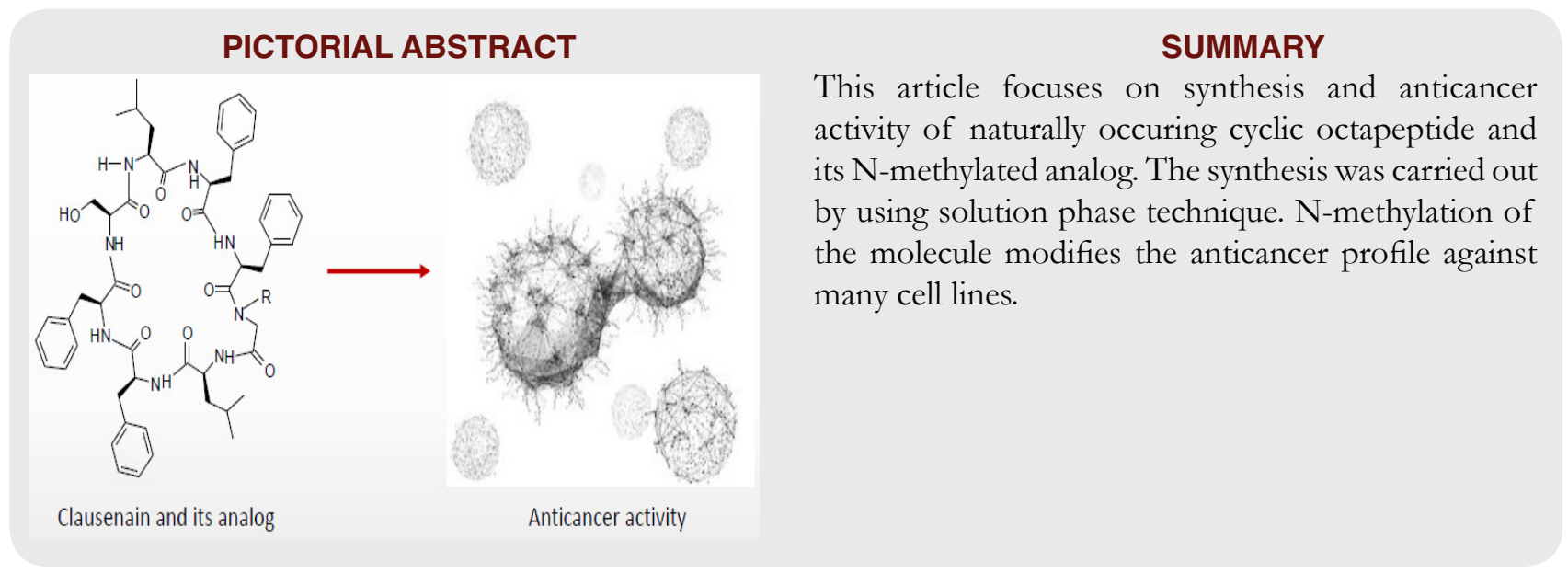




\section{About Authors}

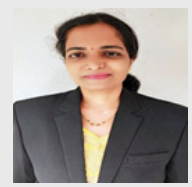

Dr. Nirmala Shinde, completed B.Pharm from Maharshtra college of Pharmacy, SRTMU, Nanded and M. Pharm in pharmaceutical chemistry from RGUHS, Bangalore in 2006. She carried out Ph.D research work under the guidance of Dr. A.S. Dhake and Dr. K. P. Haval and obtained a Ph.D degree in 2017 from Jawaharlal Nehru Technological University, Kakinada. Presently she is working as Associate professor at S.M.B.T. College of Pharmacy, Dhamangaon, Nashik. Her area of research interest includes Synthesis of peptides, amino acid conjugates for development of anticancer analogs.

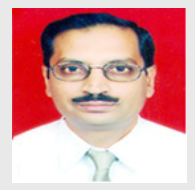

Dr. Avinash Shridhar Dhake, completed B.Pharm from Government college of Pharmacy, Karad and Ph.D in Technology from Bombay College of Pharmacy under the guidance of Dr.Tipnis. He has co-authored many books in pharmaceutical chemistry. He has vast research experience and his area of research includes biopharmaceutics, phytochemistry, synthesis and QSAR. He has guided number of students for PG and Ph.D research work.

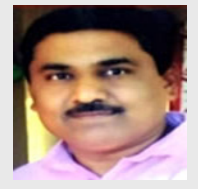

Dr. Kishan Prabhu Haval, completed M.Sc. in Organic Chemistry and obtained Ph.D from National Chemical Laboratory, Pune. Presently he is working as Assistant Professor at Department of Chemistry, Dr. Babasaheb Ambedkar Marathwada University, Sub centre: Osmanabad. He is actively involved in research and guiding 6 students for Ph.D Reaearch work. His research thrust area is organic chemistry.

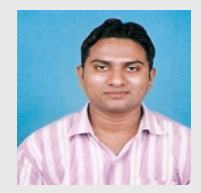

Dr. Sachin Kawaduji Bhosale, completed B.Pharm from M.V.P's College of Pharmacy, Nashik, SPPU, Pune and M.Pharm in pharmaceutical chemistry from IPER, Wardha, Sant Tukadoji Maharaj University, Nagpur in 2006. He carried out Ph.D research work under the guidance of Dr. S. R. Deshpande and obtained a Ph.D degree in 2017 from Jawaharlal Nehru Technological University, Hyderabad. Presently he is working as Assistant professor at S.M.B.T. College of Pharmacy, Dhamangaon, Nashik. His area of research interest includes Synthesis and anticancer screening of heterocyclic molecules.

Cite this article: Shinde N, Dhake AS, Haval KP, Bhosale SK. Total Synthesis of Clausenain, a Cyclic Octapeptide and its Analog for Anticancer Activity. Indian J of Pharmaceutical Education and Research. 2020;54(2s):s330-s336. 